\title{
Possibility of heat recovery from gray water in residential building
}

\author{
Aleksandra Mazur, Daniel Słyś \\ Rzeszów University of Technology \\ Faculty of Civil and Environmental Engineering and Architecture \\ Department of Infrastructure and Waste Management \\ e-mail: a.mazur@prz.edu.pl,daniels@prz.edu.pl
}

\begin{abstract}
Recovery of waste heat from gray water can be an interesting alternative to other energy saving systems in a building, including alternative energy sources. Mainly, due to a number of advantages including independence from weather conditions, small investment outlay, lack of user support, or a slight interference with the installation system. The purpose of this article is to present the financial effectiveness of installations which provide hot, usable water to a detached house, using a Drain Water Heat Recovery (DWHR) system depending on the number of system users and the various combinations of bathing time in the shower, which has an influence on the daily warm water demand in each of the considered options. The economic analysis of the adopted installation variants is based on the Life Cycle Cost (LCC) method, which is characterized by the fact that it also includes the operating costs in addition to the capital expenditure during the entire analysis period. For each case, the necessary devices were selected and the cost of their installation was estimated.
\end{abstract}

Key words: heat recovery, heat exchanger, hot water, DWHR, Life Cycle Cost, LCC

\section{Introduction}

In recent years there has been intensive development of energy efficient buildings, including passive and zero energy. This results in a change in the structure of energy consumption in buildings - an increasing share of primary energy is in the preparation of hot water and less participation lies in using the central heating. This fact makes current alternatives to the saving of water and the energy required to heat it. For this purpose, most installations use renewable energy sources, which is the subject of numerous publications [1,2,3]. On the other hand, the recovery of waste heat from gray water, especially in Poland, is very rarely used, although more and more frequently appearing publications point to the desirability of using this precipitation source to generate energy in both single-family (detached) [4,5] and multifamily buildings [6,7]. DWHR horizontal and vertical heat exchangers are the most commonly used energy recovery equipment deposited in the gray water in the construction 
sector. A number of available solutions can be found on the market and their use is described in the literature $[8,9]$.

The purpose of this article is to verify the profitability of vertical pipe heat exchangers, of the type "pipe in pipe" in the soil pipe discharging the gray water from the shower tray, compared to the traditional hot water supply system with only a condensing gas boiler. In order to determine the impact of various parameters on the financial performance of the system, variable data on the number of inhabitants and the duration of their bathing in the shower were taken, which has a direct influence on the daily demand for hot water.

\section{Installation variants}

For the analysis, 3 variants of systems which supply a single-family house with hot water have been adopted:

- Variant 0: traditional installation with condensing gas boiler with hot water storage tank;

- Variant 1: installation of condensing gas boiler with hot water storage tank additionally equipped with vertical pipe heat exchanger DWHR1, of the type "pipe in pipe" height 1200 $\mathrm{mm}$;

- Variant 2: installation with condensing gas boiler with hot water storage tank additionally equipped with vertical pipe heat exchanger DWHR2 "pipe in pipe" with a height of $1600 \mathrm{~mm}$. Heat exchangers of different heights were used for the analysis, due to the different efficiency of their operations. The scheme of the installations under consideration in variants 1 and 2 is shown in Figure 1, which assumes that the preheated hot water is directed to both - the hot water tank and the shower battery. In addition, this figure also shows how the "pipe in pipe" type heat exchanger works, which consists of a counter-current flow of hot, consumed water and cold water supplied from the water supply network.

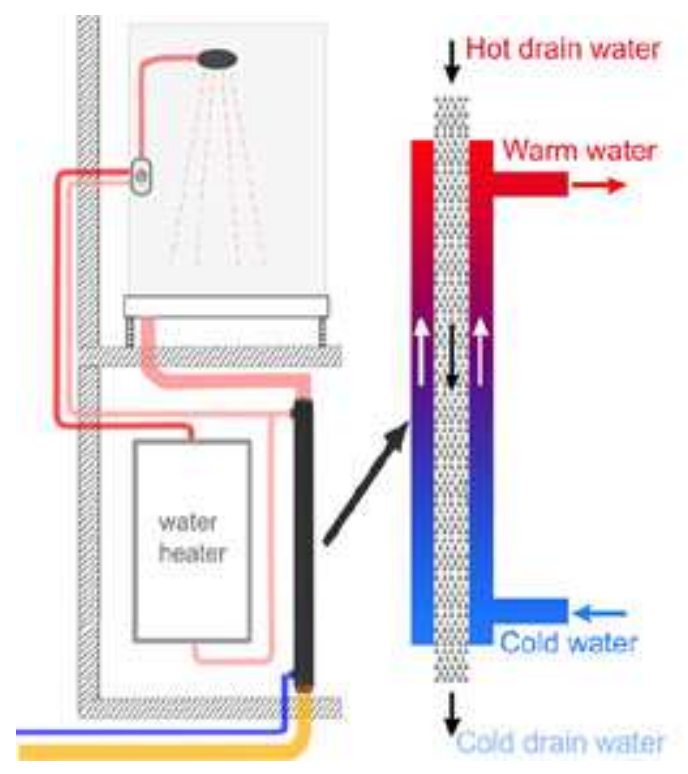

Figure 1: Installation diagram with vertical heat exchanger [10] 


\section{Methodology}

The legal basis for determining the annual requirement for the energy used to prepare the hot water $\mathrm{Q}_{\mathrm{w}, \mathrm{nd}}[\mathrm{kWh} / \mathrm{yr}]$, and then annual operating costs for each variant analyzed is the Ordinance of the Minister of Infrastructure and Development of 27 February 2015 on methodology for designating the energy performance of a building or part of a building and energy characteristics certificates [11]. Operating costs include not only the amount of fuel necessary for the heating of hot water, in this case natural gas, but also the operating costs of auxiliary equipment such as circulating pumps or an auxiliary drive and boiler controls. Calculations in this regard were made using the ArCaDiA-TERMO 6.6 computer program for the data compiled in Table 1.

Table 1: Data used for calculations

\begin{tabular}{|c|c|}
\hline Parameter & Parameter value \\
\hline The number of occupants & $3,4,5$ persons \\
Daily hot water consumption in washbasins & $6 \mathrm{~L} /$ person/day \\
Daily hot water consumption for cooking & $2 \mathrm{~L} /$ person/day \\
Daily hot water consumption for cleaning & $3 \mathrm{~L} /$ person/day \\
Daily hot water consumption for washing the dishes & $5 \mathrm{~L} /$ person/day \\
Hot water temperature & $55^{\circ} \mathrm{C}$ \\
Cold water temperature $T_{c}$ & $10^{\circ} \mathrm{C}$ \\
The temperature of the mixed water flowing out of the showerhead & $40^{\circ} \mathrm{C}$ \\
Mixed water flow from the showerhead & $9 \mathrm{~L} / \mathrm{min}$ \\
Shower length & $4,6,9 \mathrm{~min} / \mathrm{person} /$ day \\
Performance of DWHR1 heat exchanger & $52,7 \%$ \\
Performance of DWHR2 heat exchanger & $60,1 \%$ \\
Water loss coefficient in the shower and tubes $x$ & 0,95 \\
The efficiency of the hot water preparation system & $68 \%$ \\
\hline
\end{tabular}

In order to determine the amount of energy that can be saved by equipping the hot water system with a vertical heat exchanger, the model presented in publication [12] is used, according to which the daily amount of energy saved is calculated using formula (1):

$$
E_{w}=V_{W} \cdot \rho_{w} \cdot \gamma_{w} \cdot \Delta T[k W h / d]
$$

where:

$V_{W}$ - the volume of shower water consumed per day $\left[\mathrm{dm}^{3} / \mathrm{d}\right]$,

$\rho_{W}$ - specific gravity of water at $20^{\circ} \mathrm{C}\left[\mathrm{kg} / \mathrm{m}^{3}\right]$,

$\gamma_{w}$ - specific heat of water $[\mathrm{J} / \mathrm{kg} \cdot \mathrm{K}]$,

$\Delta T$ - increase in water temperature $\left[{ }^{\circ} \mathrm{C}\right]$.

The water temperature rise can be determined using the formula (2):

$$
\Delta T=\eta_{w} \cdot\left(T_{z} \cdot x-T_{e}\right)\left[{ }^{\circ} \mathrm{C}\right]
$$

where:

$\eta_{w}$ - performance of heat exchanger [\%], 
$T_{z}$ - the temperature of the mixed water flowing out of the showerhead $\left[{ }^{\circ} \mathrm{C}\right]$,

$x$ - water loss coefficient in the shower and tubes [-],

$T_{0}$ - cold water temperature $\left[{ }^{\circ} \mathrm{C}\right]$.

The LCC (Life Cycle Cost) method was used to determine the financial performance of selected variants providing hot usable water to a detached house using DWHR supply system. This concept takes into account the total life cycle cost of a product /premises/system and the cost of purchasing, owning, using, maintaining, disposing or utilization, etc. It is also characterized by a discounted nature, so it takes into account the change in the value of money over time [13]. This type of analysis is extremely helpful when choosing an investment option as it takes into account all the costs associated with using the installation system throughout its life cycle. The LCC life cycle cost can be calculated using the formula (3):

$$
L C C=I N V+\sum_{t=1}^{T}(1+r)^{-t} \cdot O C_{t}+R V
$$

where:

$I N V$ - investments [€],

$T$ - duration of the $L C C$ analysis [years],

$r$ - constant discount rate [-],

$t$ - another year of the system use [year],

$O C_{t}$ - operating costs in the year $t[€]$,

$R V$ - residual value $[€]$

In this case, the operating life of the installation system exceeds the length of the economic analysis period, it is assumed that the costs of shutdown will not be included in the calculations, which is in line with the guidelines in publication [14] according to which, in justified situations, the use a zero value of the shutting down costs is accepted. In addition, an annual increase of $3 \%$ in energy prices was assumed. A summary of the data for financial analysis is provided in Table 2.

Table 2: Data used in the calculation of LCC costs

\begin{tabular}{|c|c|}
\hline Parameter & Parameter value \\
Analysis period $T$ & 20 years \\
The discount rate $r$ & $5 \%$ \\
The cost of purchasing electricity in the year 0 & $0,135 € / \mathrm{kWh}$ \\
The annual increase in electricity prices & $3 \%$ \\
The cost of purchasing gas in the year 0 & $0,485 € / \mathrm{m}^{3}$ \\
The annual increase in electricity prices & $3 \%$ \\
The cost of buying a gas condensing boiler & $€ 1891$ \\
The cost of buying a hot water tank & $€ 378, € 414, € 527$ \\
connection set & $€ 355$ \\
Installation cost of the boiler and storage tank with accessories & \\
The cost of buying DWHR1 exchanger together with the & \\
connection set & $€ 480$ \\
The cost of buying DWHR2 exchanger together with the & \\
The cost of installing a heat exchanger with accessories & \\
\hline
\end{tabular}


Prices of electricity and natural gas were based on local data. The costs of purchasing the necessary components and their parameters are read from the catalogs of the manufacturers. Condensing gas boiler MCR3 and SR100W, SR150W, SR200W hot water cylinders of the De Dietrich company [15] selected based on the number of inhabitants and daily domestic hot water demand. DWHR1 vertical heat exchangers were also used in calculations: Showersave QB1-12 and DWHR2: Showersave QB1-16 manufactured by Q-Blue [16].

\section{Analysis of the results}

The estimated seasonal demand for hot water, capital expenditures, operating costs in the first year of use and life cycle costs for each of the analyzed versions of hot water supply systems for a detached house are summarized in Table 3.

Table 3: Calculation results

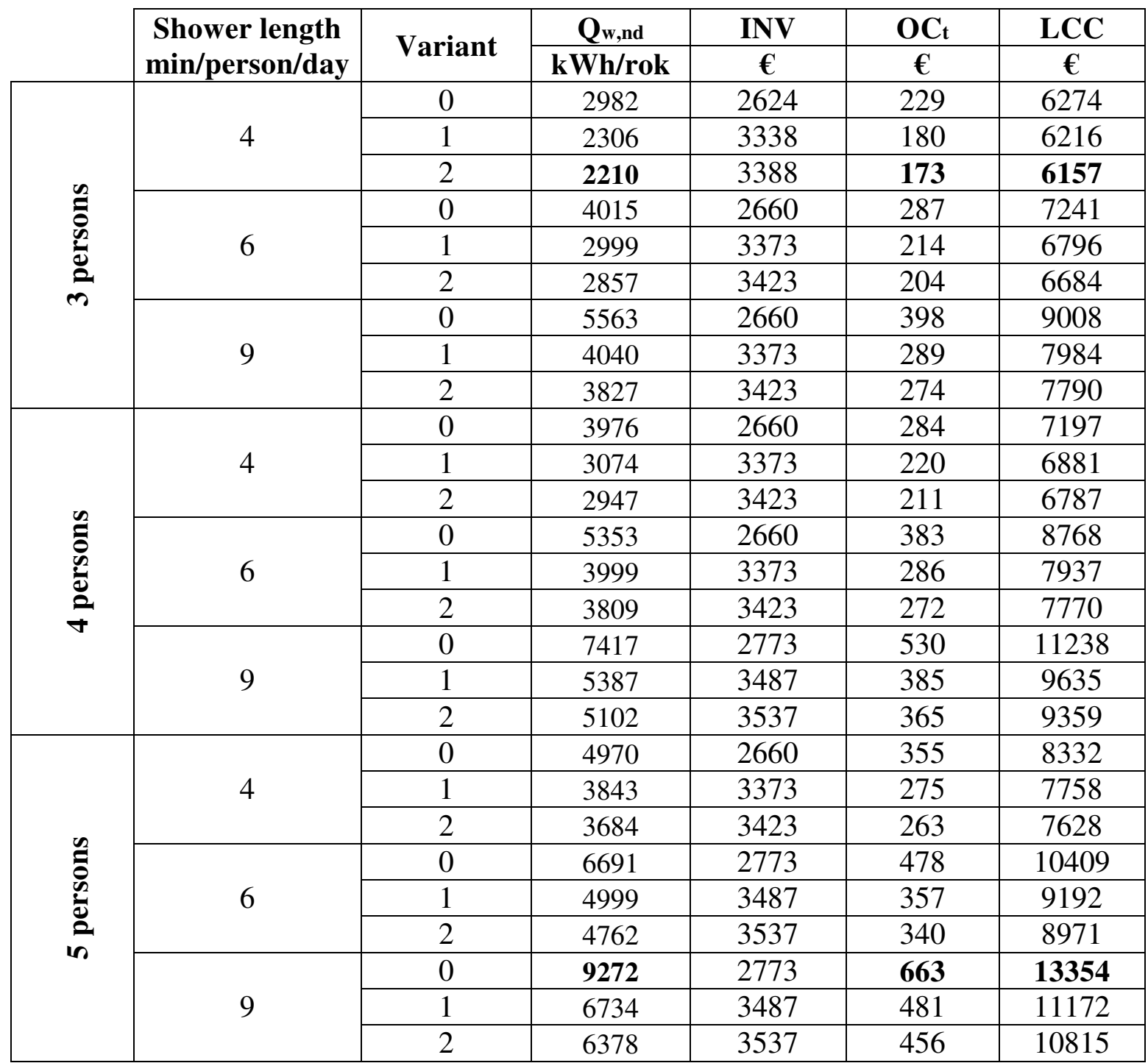


Based on the results of the calculations, the tendency is that the use of a DWHR heat exchanger in each case reduces the energy demand for hot water production, which directly triggers lower operating costs for facility users and the amount of recycled energy from gray water is directly proportional to the daily amount of water used for bathing. Considering the variants analyzed, the use of a heat recovery system in a single-family house reduces the annual utility demand for domestic hot water in the range of 23 to $31 \%$, which translates into a difference in annual operating costs of $€ 6$ for variant 1,3 inhabitants and shower duration $4 \mathrm{~min} /$ person/day up to $€ 207$ for variant 2, 5 inhabitants and shower duration of $9 \mathrm{~min} /$ person/day.

It is also evident that the lowest LCC values are in variant 2, which is best illustrated in Figure 2, which shows the results of the LCC analysis for all cases. This is due to the use of a higher-than-capacity variant 1 for the heat exchanger, so that more energy can be obtained from the gray water. There is therefore a relationship between the height of the device and its energy efficiency. It is therefore preferable to install higher-end devices even if the investment outlay is higher, as a result of the calculations made, although this choice should always be supported by detailed analysis.

In the context of twenty years of operation of a plant, the direct economic profitability of the facility's users resulting from the installation of the heat exchanger, including the cost of installation and annual operating costs, is $€ 59$ for variant 1,3 inhabitants and shower duration of $4 \mathrm{~min} /$ person/day. $€ 2539$ for variant 2, 5 inhabitants and shower duration of $9 \mathrm{~min} /$ person/day.

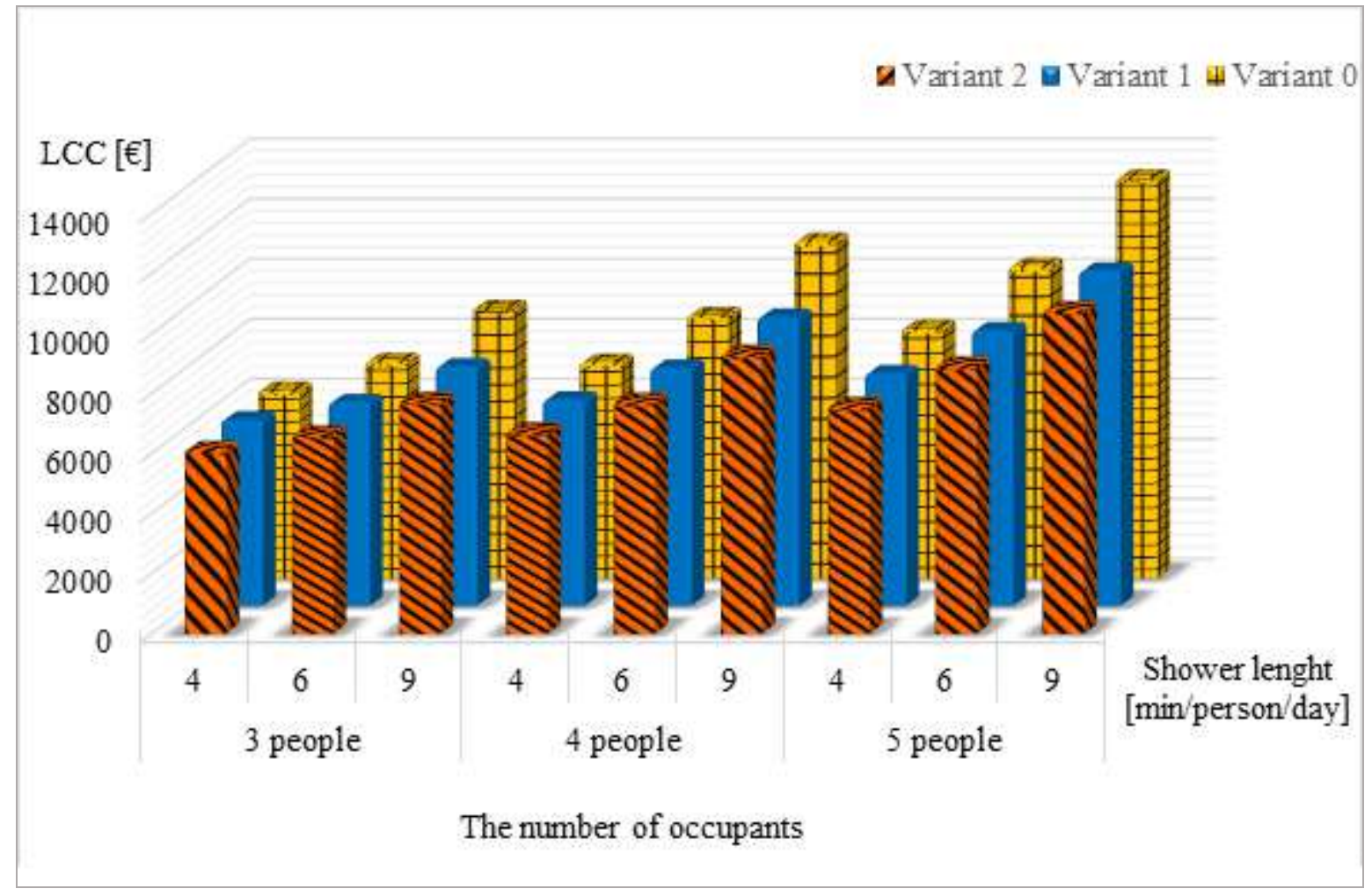

Figure 2: Comparison of Life Cycle Cost analysis results 
The use of a gray water heat recovery system has several advantages: it is cost-effective (in each of the cases analyzed, the life cycle cost of the system was lower than the exchanger variant), it does not require a high investment expenditure ("pipe in pipe" heat exchanger cost and installation costs are usually less than €1000), it does not involve the need for user service, and every day during each bath generates savings. Most importantly, this translates into environmental protection, since the recovered energy is "pure" energy, and its processing does not involve the need for fuel.

\section{Conclusion}

The use of financial analysis based on the Life Cycle Cost method makes it possible to choose the most economical and cost-effective option, assuming the calculation of all costs in the perspective of the twenty-year life of the system. The performed LCC analysis showed that Variant 0 , despite the lowest capital expenditure, was characterized by the highest life cycle cost regardless of other accepted parameters. In each case analyzed, the fitting of DHW systems into the vertical pipe heat exchanger DWHR, of the type "pipe in pipe" (Variant 1 and 2) turned out to be a viable investment, and the life cycle costs of these systems were always lower than for traditional systems.

The use of heat recovery systems reduces the amount of energy required for domestic hot water production in the analyzed cases by up to $31 \%$, which triggers the reduction in the amount of external energy required, mainly from fossil fuel fields. This is of great importance for sustainable economic development, as it helps to reduce the consumption of nonrenewable raw materials, reduce greenhouse gas emissions and, consequently, improve the environment.

\section{References}

[1] Szul, T. Technical and economic evaluation of the heating systems using electric energy. Agricultural, Horticultural and Forest Engineering, no. 1, 2016, p.12-15.

[2] Sun, X., Dai, Y., Novakovic, V., Wu, J., Wang, R. Performance comparison of the direct expansion solar-assisted heat pump and conventional air source heat pump for domestic hot water. Energy Procedia, vol 70, 2015, p.394-401.

[3] Self, S.J., Reddy, B.V., Rosen, M.A. Geothermal heat pump systems: Status review and comparison with other heating options. Applied Energy, vol. 101, 2013, p. 341-348.

[4] Stec, A., Kordana, S., Słyś, D. Analysis the financial efficiency of use of water and energy saving systems in single-family homes. Journal of Cleaner Production, vol. 151, 2017, p.193205.

[5] McNabola, A., Shields, K. Efficient drain water heat recovery in horizontal domestic shower drains. Energy and Buildings, vol. 59, 2013, p.44-49.

[6] Czarniecki, D., Pisarev, V., Dziopak, J., Słyś, D. Technical and economic analysis of the application of the wastewater heat recovery system in an apartment building. Interdisciplinary Problems in Environmental Protection and Engineering, vol. 4, Wrocław 2014.

[7] Stec, A., Kordana, S. Analysis of profitability of rainwater harvesting, gray water recycling and drain water heat recovery systems. Resources, Conservation and Recycling, vol. 105, Part A, 2015, p.84-94. 
[8] Słyś, D., Kordana, S. Odzysk ciepła odpadowego w instalacjach i systemach kanalizacyjnych. Wydawnictwo i Handel Książkami „KaBe” (Waste heat recovery in sewage installations and systems. „KaBe” Publishing House and Book Trade), Krosno, 2013.

[9] Stec, A., Słyś, D. Instalacje ekologiczne w budownictwie mieszkaniowym. Wydawnictwo i Handel Książkami „KaBe” (Ecological installations in residential buildings. „KaBe” Publishing House and Book Trade), Krosno 2016.

[10] http://www.smartclima.com/drain-water-heat-recovery.htm (accessed June 2017).

[11] Journal of Laws of 2015, item 376, Rozporządzenie Ministra Infrastruktury i Rozwoju z dnia 27 lutego 2015 r. w sprawie metodologii wyznaczania charakterystyki energetycznej budynku lub części budynku oraz świadectw charakterystyki energetycznej (Regulation of the Minister of Infrastructure and Development of 18 February 2015 on the methodology for determining the energy performance of a building or part of a building and energy performance certificates).

[12] Fidewicz, S. Wykorzystanie ciepła odpadowego jako działanie proefektywnościowe w dziedzinie gospodarki energetycznej (Exploitation of waste heat as pro-effectiveness actions in in the field of energy management). Biblioteka Źródłowa Energetyki Prosumenckiej, 2015 Available:http://ilabepro.polsl.pl/spep/raporty/energetyka-odpadowa/Fidewicz\%20Sz.\%20Ciep \%C5\%820\%20odpadowe\%20w\%20domu..pdf (accessed June 2017).

[13] Dziaduch, I. Life cycle costing models: literature review. Logistics, vol. 2, 2010, The Institute of Logistics and Warehousing.

[14] Life Cycle Cost Handbook. Guidance for Life Cycle Cost Estimation and Analysis. Office of Acquisition and Project Management, U.S. Department of Energy, Washington. Available: http://www.energy.gov/sites/prod/files/2014/10/f18/LCC\%20Handbook\%20Final\%20Version\% 209-30-14.pdf (accessed June 2017).

[15] De Dietrich, De Dietrich Brochures http://dedietrich.pl (accessed June 2017).

[16] Q-Blue, Q-Blue brochures http://www.q-blue.nl (accessed June 2017). 